This PDF is a selection from an out-of-print volume from the National Bureau of Economic Research

Volume Title: Regional and Global Capital Flows: Macroeconomic Causes and Consequences, NBER-EASE Volume 10

Volume Author/Editor: Takatoshi Ito and Anne O. Krueger, editors

Volume Publisher: University of Chicago Press

Volume ISBN: 0-226-38676-7

Volume URL: http://www.nber.org/books/ito_01-1

Publication Date: January 2001

Chapter Title: Sterilization and the Capital Inflow Problem in East Asia, 1987-97

Chapter Authors: Shinji Takagi, Taro Esaka

Chapter URL: http://www.nber.org/chapters/c10735

Chapter pages in book: (p. $197-226)$ 


\title{
Sterilization and the Capital Inflow Problem in East Asia, 1987-97
}

\author{
Shinji Takagi and Taro Esaka
}

\subsection{Introduction}

At the end of the 1980s, a large volume of capital began to flow into the emerging market economies of East Asia, owing to both external (or "push") and internal (or "pull") factors. ${ }^{1}$ Among other things, the factors that were external to the recipient countries included the lower interest rates, recessions, and regulatory changes favoring international portfolio diversification, all taking place in the industrialized world. The factors that were internal to the recipients included their sound economic policies (supported, for instance, by trade and capital market liberalization), exchange rate stability and deposit guarantees, and strong economic fundamentals. Roughly, the beginning of the surge in capital inflows can be identified as 1988 for Thailand, 1989 for Malaysia and the Philippines, 1990 for Indonesia, and 1990-91 for Korea (Calvo, Leiderman, and Reinhart 1996; Bartolini and Drazen 1997; Chuhan, Claessens, and Mamingi 1998; Montiel 1998; Villanueva and Seng 1999).

East Asia led the developing world in attracting private capital flows in the late 1980s, and became the most important destination for private capital flows in the early 1990s, with its share in total global capital flows to developing countries rising from around 10 percent in the early 1980s to

Shinji Takagi is visiting professor of economics at Yale University, on leave from his position as professor of economics at Osaka University. Taro Esaka is a doctoral candidate in economics at Osaka University.

The authors thank Leonard Cheng, Takatoshi Ito, Ryuzo Miyao, Carmen Reinhart, Hiroshi Shibuya, Kazuo Yokokawa, Mahani Zainal-Abidin, and an anonymous referee for useful comments. Needless to say, the authors alone assume responsibility for any remaining errors.

1. Latin America (particularly Argentina, Brazil, Mexico, and Venezuela) was another region that attracted a large volume of capital from the late 1980s into the 1990s. 
over 40 percent in the 1990s. While the largest portion (about one-half) of capital inflows was initially foreign direct investment (FDI), an increasing amount of inflows took the form of short-term borrowing in later years (Chen and Khan 1997; Alba et al. 1998). In fact, for the period as a whole, the bulk of the capital inflows was in the form of offshore borrowing by banks and private corporations, except for Malaysia, where FDI inflows remained larger than bank and private sector borrowing (Radelet and Sachs 1998).

On an individual level, the capital inflows were massive indeed. In terms of GDP, the volume of cumulative capital inflows from 1988 to 1995 amounted to 51.5 percent in Thailand, 45.8 percent in Malaysia, 23.1 percent in the Philippines, 9.3 percent in Korea, and 8.3 percent in Indonesia. Of the two largest recipients, Malaysia received surges of massive capital inflows in 1992 and 1993, amounting to 15.3 and 23.2 percent of GDP, respectively, while Thailand received consistent flows averaging about 10 percent of GDP annually (Villanueva and Seng 1999). At the end of 1996, the balance of claims held by foreign banks against these countries stood at $\$ 261.2$ billion; of this total, $\$ 100$ billion was accounted for by Korea, $\$ 69.4$ billion by Thailand, $\$ 58.7$ billion by Indonesia, $\$ 28.8$ billion by Malaysia, and $\$ 14.1$ billion by the Philippines. Except in Korea, more than a half of these claims were the obligations of the nonbank private sector (Radelet and Sachs 1998).

Undoubtedly, capital inflows have both benefits and costs. As benefits, they promote investment and economic growth in the recipient countries, allow intertemporal smoothing in consumption, and thus raise welfare across countries. At the same time, as costs, they may lead to a rapid monetary expansion, an excessive rise in domestic demand and inflationary pressures, an appreciation of the real exchange rate, and widening current account deficits. They may even increase the vulnerability of recipients to a sudden reversal in capital flows. For these reasons, and perhaps in the light of the earlier international debt crisis, the surge in capital inflows was, almost from the inception, perceived by the recipient countries as posing a challenge for domestic macroeconomic management, and soon began to be referred to as the "capital inflow problem" in the literature on openeconomy macroeconomics (Isard 1995; Montiel 1998).

This paper will examine the extent to which a part of this capital inflow problem was policy induced in the East Asian countries of Indonesia, Korea, Malaysia, the Philippines, and Thailand during the decade preceding the outbreak of the currency crisis in July 1997. The motivation for this investigation comes from the large accumulation of official foreign exchange reserves in the recipient countries that was associated with the capital inflows. This indicated that the volume of capital inflows was in excess of the current account deficits; during this period, the reserve accumulation in each country amounted to $25-35$ percent of the total capital flows (see section 6.2 for details). The accumulation of reserves might have 
been an offsetting response to the tight stance of monetary policy, which was supported by various measures to limit the expansionary impact of reserve inflows in the first place. The paper will indirectly test whether such tight monetary policy measures - described broadly in the paper as "sterilization" - promoted additional capital inflows through keeping the level of interest rates high, by examining the effectiveness of sterilization in limiting the impact of reserve inflows on the growth of monetary aggregates. $^{2}$

The rest of the paper is organized as follows. Section 6.2 presents an overview of the capital inflow episode in the context of Indonesia, Korea, Malaysia, the Philippines, and Thailand, by emphasizing the relationship between the capital inflows and the growth of monetary aggregates. Section 6.3 summarizes the policy responses, collectively called "sterilization," taken by the East Asian monetary authorities to limit the expansionary impact of reserve inflows on the growth of monetary aggregates. Section 6.4 tests for the effectiveness of sterilization in limiting the growth of monetary aggregates, by using both time series and structural approaches. Finally, Section 6.5 presents concluding remarks.

\subsection{An Overview of the Capital Inflow Episode in East Asia}

During the capital inflow episode, the volume of capital inflows (as measured by the surplus in the capital and financial account) exceeded the deficit in the current account in all of the countries concerned, hence resulting in increases in the foreign-asset source component of the monetary base. In Indonesia, for example, there was a capital inflow of \$4,495 million against the current account deficit of \$2,988 million in 1990 (the year in which the surge of inflows began), with an increase in the foreign exchange reserve of $\$ 2,088$ million (or about 46 percent of the net capital inflows). ${ }^{3}$ For the period 1989-96, about 26 percent of the net capital inflows were accumulated as foreign exchange reserves in Indonesia.

A similar story can be told for the other countries. In Korea, the proportion of the net capital inflows which were accumulated as foreign exchange reserves was about 32 percent for the period 1992-96. It was particularly high in 1992 (when there was a net capital inflow of \$6,994 million against the current account deficit of \$3,944 million) and in 1993 (when there was a net capital inflow of $\$ 3,217$ million against the current account surplus of $\$ 990$ million). In Malaysia, almost 80 percent of the net capital inflows was accumulated as foreign exchange reserves from 1989 (when the surge

2. The exclusive emphasis of this paper is on the domestic monetary system of the recipient country, as our primary interest lies in the effectiveness of sterilization as a monetary policy measure. On the other hand, Montiel and Reinhart (1999) directly test the effect of sterilization on the volume and composition of capital inflows.

3. These balance-of-payments figures do not necessarily add up to zero because of errors and omissions. The figures are all from the IMF, International Financial Statistics. 

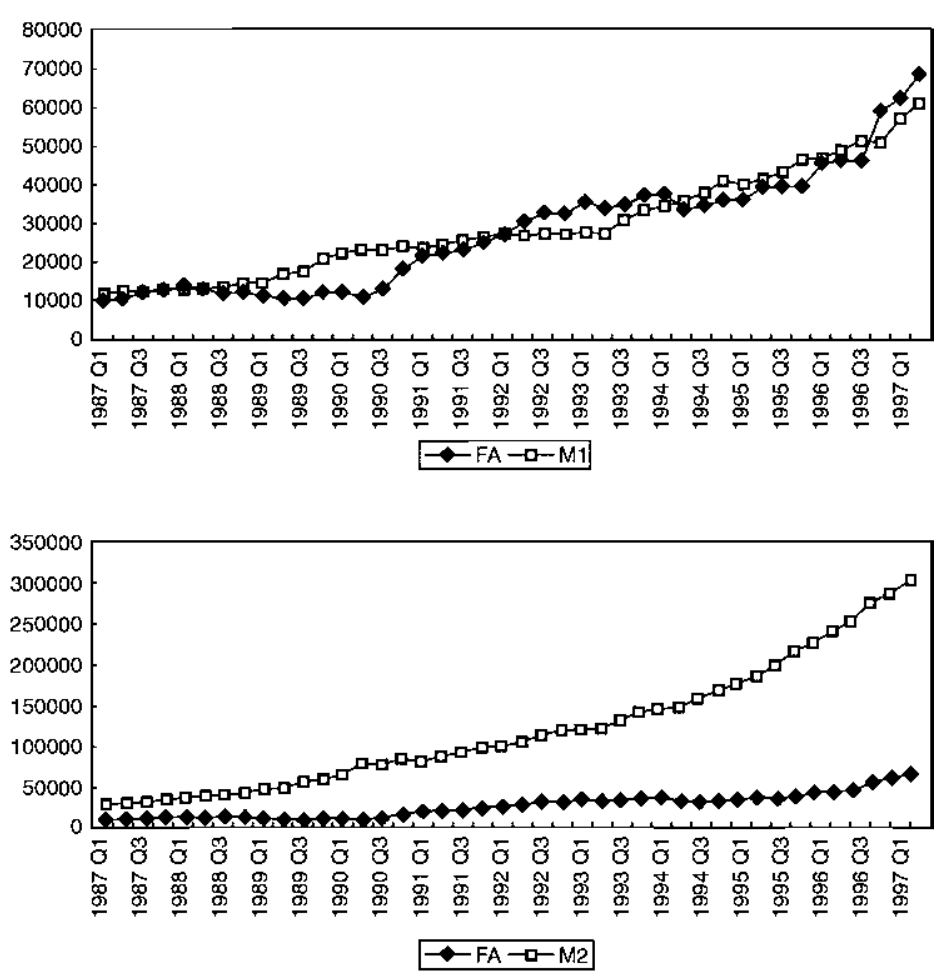

Fig. 6.1 Indonesia: Foreign assets and monetary aggregates, 1987-97 (in billions of rupiah)

Source: IMF (various months).

of inflows began) to 1993. However, it lost reserves in 1994 and 1995 before moderately gaining them again in 1996. About one-third of the net capital inflows were accumulated as foreign exchange reserves in both the Philippines and Thailand during the inflow period.

Reflecting the accumulation of foreign exchange reserves, the foreign assets (FA) source component of the monetary base rapidly expanded in these countries. ${ }^{4}$ At the same time, all the countries saw a rapid growth in both narrow and broad money (M1 and M2). In Indonesia, for example, FA rose about 5.0 times from 1989 to 1996, with M1 rising 2.5 times and M2 4.7 times during the same period; over the entire sample period, however, there seems to be a closer correspondence between FA and M1 (fig. 6.1). In Korea, FA, M1, and M2 all increased by roughly the same percent-

4. There is not necessarily a perfect correspondence between changes in the value of foreign assets held by the monetary authorities and the official settlement accounts in the balance of payments, owing to valuation and other accounting differences. 
age (i.e., 2.6 times, 1.8 times, and 2.1 times, respectively, from 1991 to 1996); one can observe volatile changes in the growth of M1 (fig. 6.2).

In Malaysia, FA rose 3.2 times from 1989 to 1996, with M1 and M2 both rising 3.6 times. Corresponding to the surge of capital inflows, there was a rapid growth in FA from 1992 to early 1994; M1 then contracted through the first part of 1995 (fig. 6.3). In the Philippines, FA rose 5.8 times from 1989 to 1996 , with M1 rising 2.9 times and M2 about 4.0 times. There were volatile fluctuations in the growth of FA; similar but more subdued fluctuations were observed for the growth of M1, sometimes displaying negative correlations between the two (fig. 6.4). Finally, in Thailand, FA rose 5.5 times from 1988 to 1996, with M1 rising 2.9 times and M2 3.9 times (fig. 6.5).

In each country, there was a sustained growth in FA, which was associated with the sustained growth in M1 and M2, hence giving rise to the common view that the surge in FA associated with the capital inflows somehow caused the rapid growth of monetary aggregates during the capital
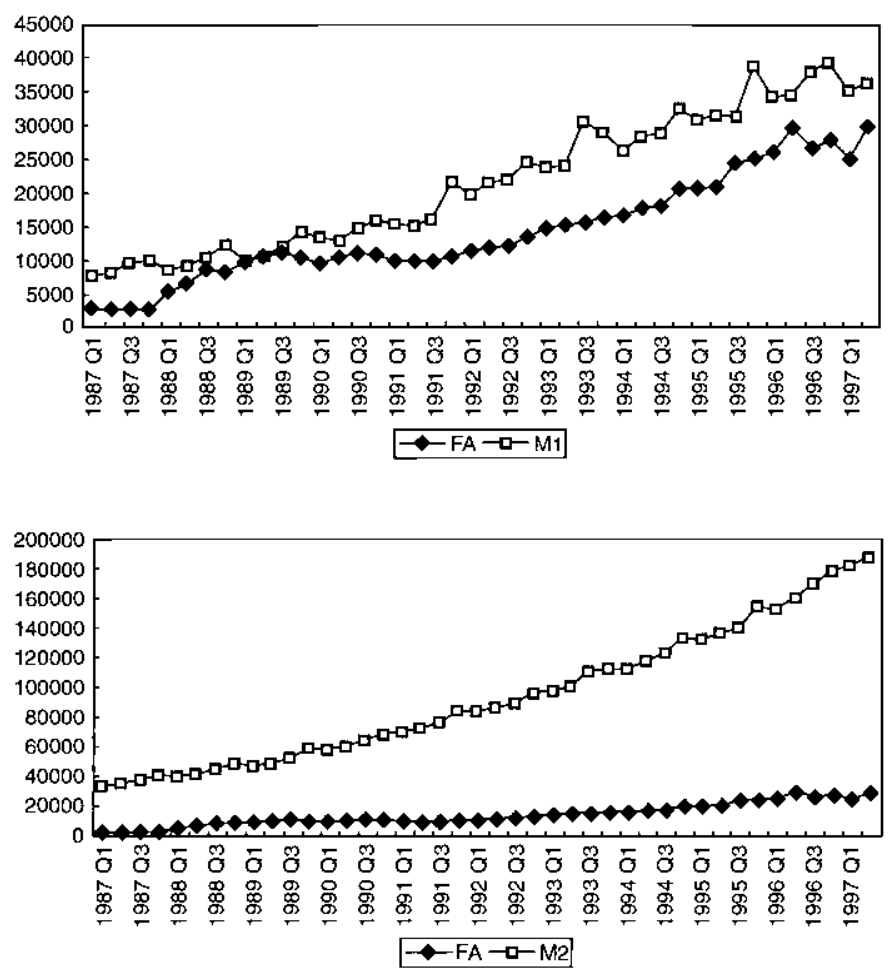

Fig. 6.2 Korea: Foreign assets and monetary aggregates, 1987-97 (in billions of won)

Source: IMF (various months). 

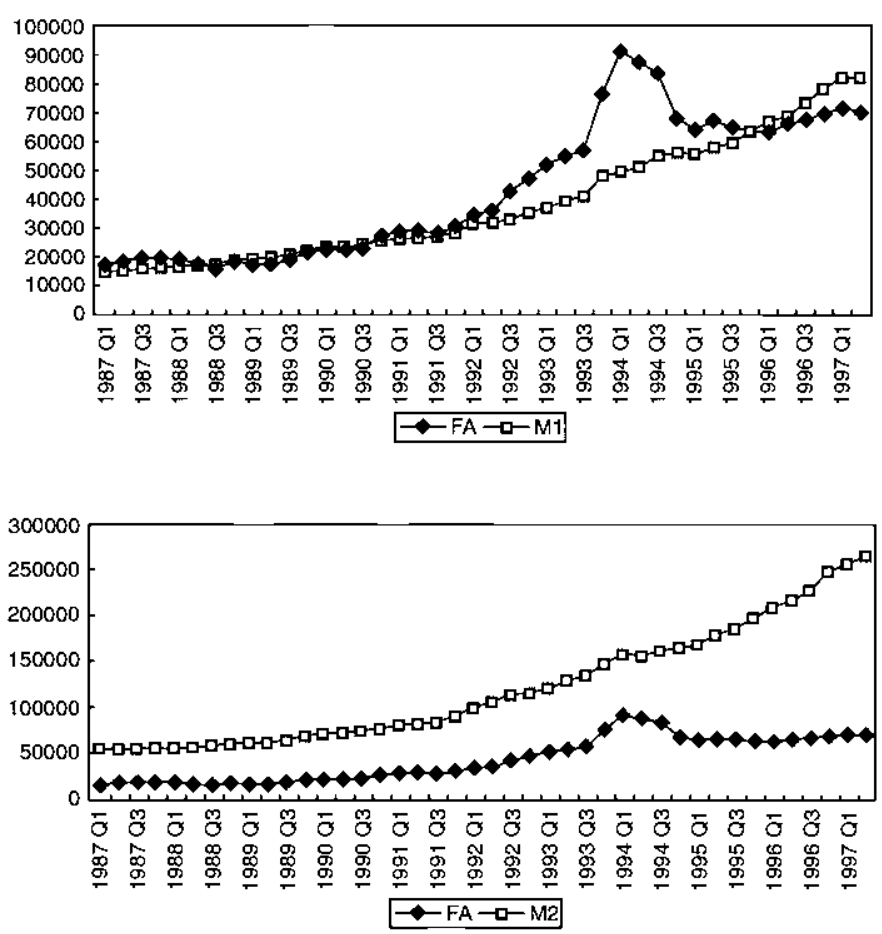

Fig. 6.3 Malaysia: Foreign assets and monetary aggregates, 1987-97 (in millions of ringgit)

Source: IMF (various months).

inflow episode. The validity of this view will be the subject of our investigation in the sections to follow.

\subsection{Policy Responses to the Capital Inflows}

As stated earlier, it was feared from the very beginning that the capital inflows might lead to a rapid monetary expansion, an excessive rise in aggregate demand and inflationary pressures, an appreciation of the real exchange rate, and widening current account deficits. For this reason, the monetary authorities of East Asian countries resorted to various policy measures to mitigate that possibility, including capital controls, trade liberalization, greater exchange rate flexibility, fiscal contraction, and a variety of monetary measures (Montiel 1998; Reinhart and Reinhart 1998; Villanueva and Seng 1999). The monetary measures, the focus of the present paper, included the conventional form of sterilized intervention (designed to offset the effect of reserve inflows on the monetary base by open market 

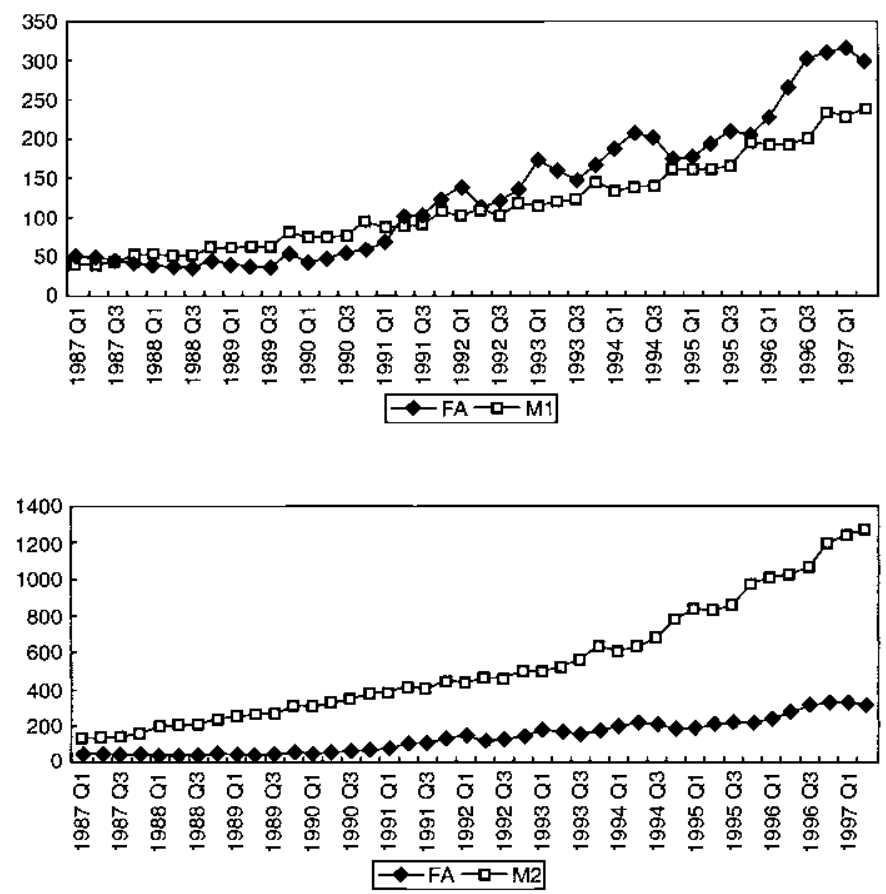

Fig. 6.4 The Philippines: Foreign assets and monetary aggregates, 1987-97 (in billions of pesos)

Source: IMF (various months).

sales of domestic securities), increases in reserve requirements (designed to limit the impact of reserve inflows on the growth of monetary aggregates by reducing the money multiplier), shifting government deposits from commercial banks to the central bank, an increase in the discount rate or otherwise a greater limit on the discount window, moral suasion, and credit controls. Of these and other monetary measures, sterilized intervention and the tightening of reserve requirements were the most common and were employed at one time or another by all of the central banks concerned.

By far, the most common and extensive was sterilized intervention, at least initially. Often lacking the depth of markets in government securities, the East Asian central banks supplemented operations in government securities by issuing their own debt instruments (Villanueva and Seng 1999). For example, in 1987, the Bank of Thailand (BOT) began to issue short-term BOT bonds with maturities of six months to one year. Monetary Stabilization Bonds (MSBs) and Bank Indonesia Certificates (SBIs) were the principal tools of open market operations used by the Bank of 

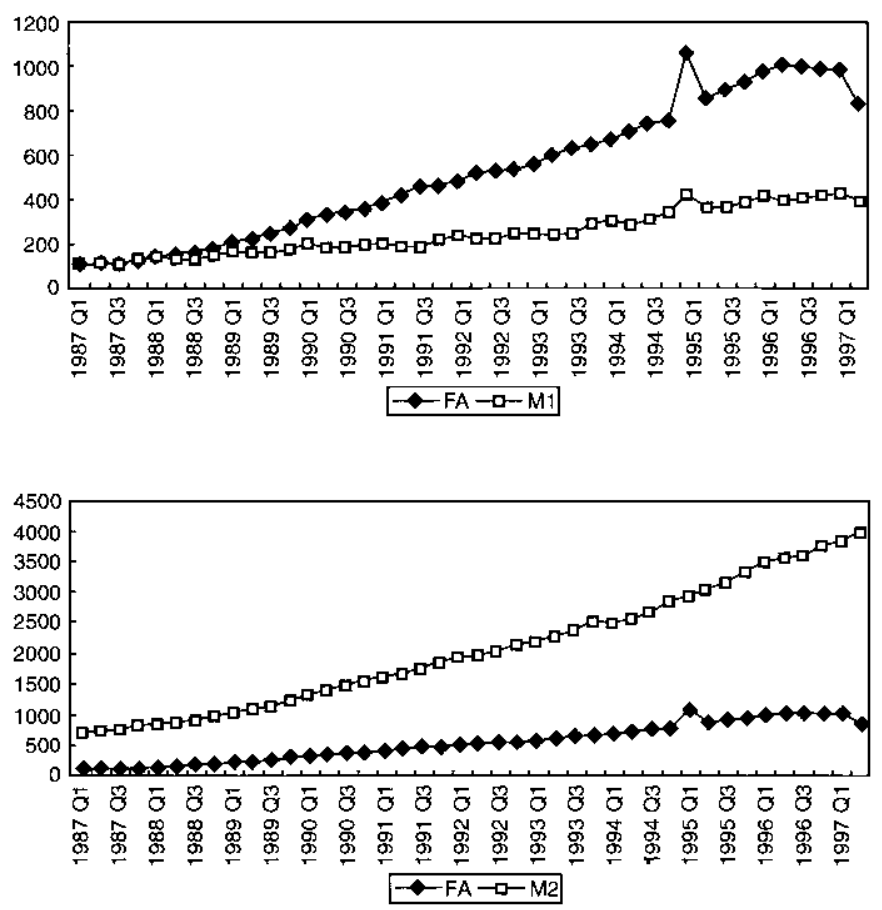

Fig. 6.5 Thailand: Foreign assets and monetary aggregates, 1987-97 (in billions of baht)

Source: IMF (various months).

Korea and Bank Indonesia, respectively. ${ }^{5}$ The Central Bank of the Philippines had routinely used Central Bank Certificates of Indebtedness (CBCIs), at least until 1994, when open market operations in government securities gained prominence. Even in Malaysia where the market for government securities is fairly well developed by East Asian standards, Bank Negara issued series of Bank Negara Bills and Malaysian Savings Bonds during the peak inflow period of $1993 .{ }^{6}$

After the initial period, however, most of the central banks began to rely much less on conventional sterilized intervention, in part owing to the quasi-fiscal costs of such operations. The quasi-fiscal cost arises because, in sterilized intervention, the central bank typically exchanges highyielding domestic assets for low-yielding foreign assets (Calvo 1991; Kletzer and Spiegel 1998). In the consolidated government and central bank

5. In Korea, the first auction in MSBs was conducted in April 1993, although they had been issued earlier. In Indonesia, SBIs were first issued in 1984.

6. In Malaysia, central bank securities were first issued in 1987. 
portfolio, the public sector ends up paying more on its liabilities than it receives on its assets, as more government debt is held outside the central bank. Villanueva and Seng (1999) identify the period of active sterilized intervention as 1988-95 for Thailand, 1989 and 1992-93 for Korea, 1990-93 and 1996 for Indonesia, 1990-93 for the Philippines, and 1992-93 for Malaysia. Thus, it was only in Thailand that sterilized intervention was used consistently throughout much of the capital inflow episode.

In addition to sterilized intervention, other measures were also used to control either the monetary base or the growth of monetary aggregates. Measures to control base money included central bank borrowing from commercial banks, and the shifting of government deposits from commercial banks to the central bank. The latter tool was frequently used in Malaysia, Thailand, and Indonesia. In Malaysia, the most important funds to be so shifted were deposits of the Employee Provident Fund (EPF). It is said that more than US\$2.6 billion in EPF funds were shifted from commercial banks to Bank Negara in 1992 (Villanueva and Seng 1999). In the Philippines, the government borrowed from the private sector to make deposits at the central bank. Access to the discount window was reduced in Korea during 1986-88, in Thailand during 1989-90, and in Malaysia during 1995-96. In Indonesia, moral suasion and various reporting requirements were imposed on commercial banks during 1994-96. Some control measures acted almost like cross-border capital controls, such as the ceiling on the external liabilities of domestic banks and the prohibition of sales of short-term financial instruments to foreigners, both imposed by Malaysia for several months during 1994.

The most common tool for containing the growth of monetary aggregates (while accepting the increase in base money itself) was to effect a rise in reserve requirements. Malaysia frequently raised reserve requirements and expanded the coverage of institutions and deposits subject to the requirements. Indonesia and Thailand, although initially reluctant to raise reserve requirements, became more active users of this tool in later years. Villanueva and Seng (1999) identify the period during which the reserve requirements were raised as 1989-92, 1994, and 1996 for Malaysia, 1990 for Korea and the Philippines, 1995-96 for Thailand, and 1996 for Indonesia.

In this paper, as elsewhere in the recent literature on this subject, what we call sterilization includes not only the conventional form of sterilized intervention (in which domestic and foreign securities are exchanged in an open market transaction), which may be termed "sterilization in the narrower sense," but also any form of transaction which is designed to limit the impact of reserve inflows on the growth of monetary aggregates, which may be termed "sterilization in the broader sense." Whether it is defined narrowly or broadly, sterilization tends to raise the level of domes- 
tic interest rates, provided that foreign and domestic assets are imperfect substitutes and sterilization is thus effective. ${ }^{7}$

In the case of narrowly defined sterilization, domestic interest rates rise so as to induce the market participants to hold the greater amount of domestic assets willingly. In the case of broadly defined sterilization, domestic interest rates rise so as to clear the money market, given the restricted money supply. In either case, a rise in foreign assets would be prevented from increasing the volume of monetary aggregates at least one to one, and the resulting rise in interest rate differentials favoring the domestic assets would promote additional capital inflows, given flexible but stable nominal exchange rates (Takagi 1999). Of course, no additional capital inflows would result if the market participants correctly perceived that the higher interest rates only reflected the higher risk premium of domestic assets and the nonzero probability of currency depreciation. However, it is said that many market participants tried to exploit the interest rate differentials that existed between U.S. dollar-denominated and East Asian currency-denominated assets by taking unhedged short-term positions for supposed financial gains, believing that the markets were imperfect (Furman and Stiglitz 1998, particularly n. 34).

\subsection{Estimating the Effectiveness of Sterilization}

The foregoing discussion makes it clear that, in testing for the effectiveness of sterilization, the conventional method of estimating the offset coefficient of the capital flow equation along with the monetary policy reaction function would be inappropriate in the context of the East Asian experience (for an example of the conventional method applied to developing countries, see Takagi 1986). In East Asia, various monetary measures were used at various times in various intensities in order to sterilize the effect of capital inflows on the growth of monetary aggregates. For this reason, in what follows, we will test for the effectiveness of sterilization by estimating the extent to which foreign assets (FA) in the monetary base explains or predicts monetary aggregates, setting aside the question of how sterilization is actually effected.

We will use quarterly data for the ten-year period from the first quarter of 1987 through the second quarter of 1997, immediately preceding the outbreak of the Thai crisis in July 1997. Both narrow money (M1) and broad money (M2) are used as measures of monetary aggregates, and consumer price indexes are used as the price level $(P)$. For Korea and the Philippines, real GDP is used for output $(Y)$, whereas industrial production is used for the other three countries. For the interest rate $(i)$, the money

7. It should be noted that, in practice, sterilization was generally supported by tight fiscal policy, which reinforced the upward pressure on the level of interest rates. 
market rate is used (see the appendix for the sources and descriptions of the data). Table 6.1 summarizes the time series properties of the variables, where all but the interest rate are expressed in natural logarithm. The table overwhelmingly suggests that the variables are integrated of order one, that is, $I(1)$. The only exceptions are nominal and real FA, and $Y$ in Thailand. Although not formally reported in the table, all the variables are found to become stationary when they are differenced once.

\subsubsection{Cointegration Tests}

Before proceeding further, we test for the presence of cointegration between money and foreign assets by using Johansen's (1988) trace tests, with lag length chosen by Schwarz' Bayesian information criterion (SBIC). In a bivariate system (expressed in natural logarithm), we find that neither M1 nor M2 is found to be cointegrated with FA, except for M2 in Indonesia (table 6.2). In a multivariate system (consisting of real M1 or M2, real FA, $i$, and $Y$, where all but $i$ are expressed in natural logarithm), a cointegrating relationship is found only for M1 in the Philippines. In what follows, given the overwhelming evidence that all variables are $I(1)$ and the general absence of cointegration, we will estimate regression equations in first difference form without an error correction term.

\subsubsection{Granger Causality Tests}

First, we will test for Granger causality between money and foreign assets. A stationary time series $x$ (e.g., FA) is said to Granger-cause a stationary time series $z$ (e.g., M1 or M2), if the hypothesis that the coefficients $c_{j}$ are collectively zero can be rejected at a given level of significance.

$$
z_{t}=a+\sum b_{j} z_{t-j}+\sum c_{j} x_{t-j}+s w+e_{t}
$$

where $t$ is a time subscript, $a$ is a constant, $\Sigma$ is a summation from 1 to $k$ (where lag length $[k]$ is chosen by SBIC), $b_{j}$ 's are the coefficients of the lagged dependent variables, $w$ is a vector of other variables, including seasonal dummies (and, in a multivariate system, the lagged values of other variables, such as output and the interest rate), $s$ is a vector of coefficients associated with $w$, and $e$ is a random error term. Both causality from FA to M1 or M2 and causality from M1 or M2 to FA are tested, although only the first type of causality, which is the focus of this paper, is discussed in the text below. ${ }^{8}$

In a bivariate system with FA and M1 or M2 (in logarithmic differ-

8. As we are considering the impact of a change in FA on monetary aggregates (which must be effected through the banking sector and presumably takes some time), we believe that the use of quarterly data is appropriate. If the adjustment of monetary aggregates in response to a change in FA is completed quickly within a quarter, however, Granger causality is not revealed in quarterly data. 


\begin{tabular}{|c|c|c|}
\hline Variables & Seasonal Dummies & Time Trend \\
\hline \multicolumn{3}{|l|}{ Indonesia } \\
\hline $\ln \mathrm{M} 1$ & $-0.320(4)[0.922]$ & $-2.904(4)[0.160]$ \\
\hline $\ln \mathrm{M} 2$ & $-0.920(3)[0.781]$ & $-2.009(3)[0.596]$ \\
\hline $\ln \mathrm{FA}$ & $-0.112(3)[0.948]$ & $-2.666(4)[0.250]$ \\
\hline $\ln (\mathrm{M} 1 / P)$ & $-0.741(2)[0.835]$ & $-2.642(2)[0.260]$ \\
\hline $\ln (\mathrm{M} 2 / P)$ & $-1.009(3)[0.749]$ & $-2.090(3)[0.552]$ \\
\hline $\ln (\mathrm{FA} / P)$ & $-0.154(3)[0.943]$ & $-2.554(4)[0.301]$ \\
\hline $\ln Y$ & $-0.312(4)[0.923]$ & $-2.544(4)[0.306]$ \\
\hline$i$ & $-2.603(2)[0.278]$ & $-2.603(2)[0.278]$ \\
\hline \multicolumn{3}{|l|}{ Korea } \\
\hline $\ln \mathrm{M} 1$ & $-1.686(3)[0.438]$ & $0.171(4)[0.995]$ \\
\hline $\ln \mathrm{M} 2$ & $-2.240(4)[0.191]$ & -1.269 (4) [0.895] \\
\hline $\ln \mathrm{FA}$ & -0.289 (4) [0.926] & -3.087 (4) [0.110] \\
\hline $\ln (\mathrm{M} 1 / P)$ & -1.367 (4) [0.597] & $-0.516(4)[0.982]$ \\
\hline $\ln (\mathrm{M} 2 / P)$ & $0.038(4)[0.961]$ & $-2.725(4)[0.225]$ \\
\hline $\ln (\mathrm{FA} / P)$ & $-0.544(4)[0.883]$ & $-2.986(4)[0.144]$ \\
\hline $\ln Y$ & $-0.661(4)[0.856]$ & -2.697 (3) [0.237] \\
\hline$i$ & $-2.079(2)[0.557]$ & $-2.079(2)[0.557]$ \\
\hline \multicolumn{3}{|l|}{ Malaysia } \\
\hline $\ln \mathrm{M} 1$ & 0.499 (2) [0.984] & $-2.396(2)[0.381]$ \\
\hline $\ln \mathrm{M} 2$ & $1.155(2)[0.995]$ & $-2.992(2)[0.134]$ \\
\hline $\ln \mathrm{FA}$ & $-0.957(3)[0.768]$ & $-1.583(3)[0.798]$ \\
\hline $\ln (\mathrm{M} 1 / P)$ & $0.220(4)[0.973]$ & $-2.376(2)[0.392]$ \\
\hline $\ln (\mathrm{M} 2 / P)$ & $1.014(2)[0.994]$ & $-2.778(2)[0.204]$ \\
\hline $\ln (\mathrm{FA} / P)$ & $-1.043(3)[0.736]$ & $-1.597(3)[0.793]$ \\
\hline $\ln Y$ & $0.520(4)[0.985]$ & $-2.191(4)[0.494]$ \\
\hline$i$ & $-1.918(3)[0.644]$ & $-1.918(3)[0.644]$ \\
\hline \multicolumn{3}{|c|}{ The Philippines } \\
\hline $\ln \mathrm{M} 1$ & 0.070 (4) [0.964] & $-1.617(4)[0.785]$ \\
\hline $\ln \mathrm{M} 2$ & $-1.643(2)[0.460]$ & $-2.071(4)[0.562]$ \\
\hline $\ln \mathrm{FA}$ & $-0.217(2)[0.936]$ & $-2.280(2)[0.444]$ \\
\hline $\ln (\mathrm{M} 1 / P)$ & 1.839 (4) [0.998] & 0.169 (4) [0.995] \\
\hline $\ln (\mathrm{M} 2 / P)$ & $-0.842(2)[0.806]$ & $-1.491(4)[0.831]$ \\
\hline $\ln (\mathrm{FA} / P)$ & $-0.261(2)[0.930]$ & $-2.679(2)[0.244]$ \\
\hline $\ln Y$ & 0.651 (4) [0.988] & $-2.131(4)[0.528]$ \\
\hline$i$ & $-2.008(2)[0.596]$ & $-2.008(2)[0.596]$ \\
\hline \multicolumn{3}{|l|}{ Thailand } \\
\hline $\ln \mathrm{M} 1$ & $-0.981(2)[0.760]$ & -2.197 (4) $[0.491]$ \\
\hline $\ln \mathrm{M} 2$ & $-2.413(3)[0.137]$ & $-1.708(4)[0.747]$ \\
\hline $\ln \mathrm{FA}$ & $-2.917(3)[0.043]^{* *}$ & $0.324(3)[0.996]$ \\
\hline $\ln (\mathrm{M} 1 / P)$ & $-1.112(2)[0.709]$ & $-2.135(4)[0.526]$ \\
\hline $\ln (\mathrm{M} 2 / P)$ & $-2.309(2)[0.168]$ & $-1.071(4)[0.933]$ \\
\hline $\ln (\mathrm{FA} / P)$ & $-2.948(3)[0.039]^{* *}$ & 0.441 (3) [0.990] \\
\hline $\ln Y$ & $-2.056(4)[0.262]$ & $-3.736(4)[0.022]^{* *}$ \\
\hline$i$ & $-2.069(2)[0.563]$ & $-2.069(2)[0.563]$ \\
\hline
\end{tabular}

Notes: The figures are augmented Dickey-Fuller statistics obtained from running a regression with a constant term and seasonal dummies (left column) or with a constant term and time trend (right column); for the interest rate only, neither seasonal dummy nor time trend is included (hence, the same statistics are reported in both columns). Lag length was chosen on the basis of Schwarz's Bayesian information criterion (SBIC). Numbers in parentheses denote lag length; those in brackets are $p$-values.

**Significant at the 5 percent level. 


\begin{tabular}{|c|c|c|c|}
\hline \multirow{2}{*}{$\begin{array}{l}\text { Cointegrating } \\
\text { Vectors }(r)\end{array}$} & \multicolumn{2}{|c|}{ Null } & \\
\hline & $r=0$ & $r \leq 1$ & \\
\hline \multicolumn{4}{|c|}{ Bivariate: M1 and FA (first row); M2 and FA (second row) } \\
\hline \multicolumn{4}{|c|}{ Indonesia } \\
\hline VAR (1) & $11.90[0.286]$ & $0.337[0.770]$ & $r=0$ \\
\hline VAR (1) & $22.99[0.012]^{* *}$ & $1.705[0.603]$ & $r=1$ \\
\hline \multicolumn{4}{|l|}{ Korea } \\
\hline VAR (3) & 8.017 [0.622] & $2.955[0.424]$ & $r=0$ \\
\hline VAR (3) & $6.574[0.735]$ & $1.976[0.565]$ & $r=0$ \\
\hline \multicolumn{4}{|l|}{ Malaysia } \\
\hline VAR (1) & $5.096[0.826]$ & $0.019[0.801]$ & $r=0$ \\
\hline VAR (1) & 6.369 [0.749] & $1.246[0.665]$ & $r=0$ \\
\hline \multicolumn{4}{|l|}{ The Philippines } \\
\hline VAR (1) & $6.036[0.771]$ & $0.005[0.803]$ & $r=0$ \\
\hline VAR (1) & $6.958[0.707]$ & $0.006[0.803]$ & $r=0$ \\
\hline \multicolumn{4}{|l|}{ Thailand } \\
\hline VAR (1) & $13.59[0.180]$ & $1.539[0.626]$ & $r=0$ \\
\hline VAR (1) & $11.12[0.347]$ & $0.555[0.747]$ & $r=0$ \\
\hline \multicolumn{4}{|c|}{$\begin{array}{c}\text { Multivariate: real M1, real FA, output and interest rate (first row); } \\
\text { real M2, real FA, output and interest rate (second row) }\end{array}$} \\
\hline \multicolumn{4}{|c|}{ Indonesia } \\
\hline VAR (1) & $39.38[0.284]$ & $19.43[0.544]$ & $r=0$ \\
\hline VAR (1) & $44.32[0.119]$ & $25.80[0.184]$ & $r=0$ \\
\hline \multicolumn{4}{|l|}{ Korea } \\
\hline VAR (1) & $36.23[0.432]$ & $10.25[0.930]$ & $r=0$ \\
\hline VAR (1) & $41.13[0.217]$ & $14.29[0.821]$ & $r=0$ \\
\hline \multicolumn{4}{|l|}{ Malaysia } \\
\hline VAR (1) & $38.60[0.318]$ & $18.52[0.602]$ & $r=0$ \\
\hline VAR (1) & $39.20[0.292]$ & $19.82[0.518]$ & $r=0$ \\
\hline \multicolumn{4}{|l|}{ The Philippines } \\
\hline VAR (1) & $55.73[0.009]^{* * *}$ & $19.85[0.516]$ & $r=1$ \\
\hline VAR (1) & $38.87[0.400]$ & $18.95[0.575]$ & $r=0$ \\
\hline \multicolumn{4}{|l|}{ Thailand } \\
\hline VAR (1) & 39.87 [0.264] & $21.27[0.424]$ & $r=0$ \\
\hline VAR (1) & $45.10[0.102]$ & $21.65[0.399]$ & $r=0$ \\
\hline
\end{tabular}

Notes: Johansen's trace tests on a vector autoregression (VAR) system with a constant term and seasonal dummies. Lag length (in parentheses) is chosen on the basis of Schwarz's Bayesian information criterion (SBIC). $r$ denotes the number of cointegrating vectors. Numbers in brackets are $p$-values.

*** Significant at the 1 percent level.

**Significant at the 5 percent level. 
Table 6.3 Granger Tests of Causality between Money and Foreign Assets, 1987-97 (bivariate VAR)

\begin{tabular}{ccc}
\hline & FA causes M & M causes FA \\
\hline \multicolumn{3}{c}{ M1 and FA (first row); M2 and FA (second row) } \\
Indonesia & $F(1,34) 0.388[0.537]$ & $F(1,34) 0.337[0.565]$ \\
VAR (1) & $F(1,34) 1.132[0.295]$ & $F(1,34) 0.022[0.882]$ \\
VAR (1) & $F(1,34) 1.421[0.241]$ & $F(1,34) 0.474[0.496]$ \\
Korea & $F(1,34) 1.638[0.209]$ & $F(1,34) 0.231[0.634]$ \\
VAR (1) & & \\
VAR (1) & $F(1,34) 4.035[0.053]^{*}$ & $F(1,34) 1.455[0.236]$ \\
Malaysia & $F(1,34) 0.000[0.991]$ & $F(1,34) 0.480[0.493]$ \\
VAR (1) & & \\
VAR (1) & $F(1,34) 0.324[0.573]$ & $F(1,34) 4.622[0.039]^{* *}$ \\
The Philippines & $F(1,34) 3.146[0.085]^{*}$ & $F(1,34) 1.349[0.254]$ \\
VAR (1) & $F(1,34) 0.039[0.845]$ & $F(1,34) 0.673[0.418]$ \\
VAR (1) & $F(1,34) 1.077[0.307]$ & $F(1,34) 4.315[0.045]^{* *}$ \\
Thailand & VAR (1) & \\
VAR (1) &
\end{tabular}

Notes: F-statistics in a bivariate VAR of money (M1 or M2) and foreign assets (FA) with a constant term and seasonal dummies. Lag length (in parentheses following VAR) was chosen on the basis of Schwarz's Bayesian information criterion (SBIC). Numbers in brackets are $p$-statistics.

**Significant at the 5 percent level.

*Significant at the 10 percent level.

ences), FA is found to Granger-cause M only in Malaysia when M1 is used and in the Philippines when M2 is used, both at the 10 percent level of significance (table 6.3). At the 5 percent level of significance, however, no Granger causality is found from FA to either M1 or M2. ${ }^{9}$ In a multivariate system with real FA, real M1 or M2, $Y$, and $i$ (in logarithmic differences, except for $i$ which is expressed in simple first difference), no Granger causality is found at the 10 percent level of significance or lower (table 6.4). To the extent that the multivariate system can generally be considered more appropriate, ${ }^{10}$ we conclude that no Granger causality was found from foreign assets to monetary aggregates during 1987-97 in any of the countries. $^{11}$

9. We have also followed the procedure of Toda and Yamamoto (1995) to apply Granger causality tests in the levels of integrated or cointegrated variables. In a bivariate system, the only evidence of causality from FA to money is found in the case of Malaysia (at the 5 percent level of significance) when M1 is used.

10. If the true model includes more variables, the bivariate system of foreign assets and money may show a spurious relationship.

11. As an additional test, we have also applied Granger causality tests in Johansen's error correction model (ECM) framework, given the possible presence of cointegration between FA and M2 in Indonesia and between real M1, real FA, $Y$, and $i$ in the Philippines (see table 
Table 6.4 Granger Tests of Causality between Money and Foreign Assets, 1987-97 (multivariate VAR)

\begin{tabular}{ccc}
\hline & FA causes M & M causes FA \\
\hline M1,,$i$, and FA (first row); M2, $Y, i$, and FA (second row) \\
Indonesia & $F(1,28) 0.000[0.975]$ & $F(1,28) 0.073[0.788]$ \\
VAR (1) & $F(1,28) 0.002[0.963]$ & $F(1,28) 0.038[0.845]$ \\
VAR (1) & $F(1,28) 1.235[0.275]$ & $F(1,28) 0.641[0.429]$ \\
Korea & $F(1,28) 1.191[0.256]$ & $F(1,28) 0.432[0.515]$ \\
VAR (1) & & \\
VAR (1) & $F(1,28) 1.520[0.227]$ & $F(1,28) 1.407[0.245]$ \\
Malaysia & $F(1,28) 0.093[0.762]$ & $F(1,28) 0.005[0.942]$ \\
VAR (1) & & \\
VAR (1) & $F(1,28) 0.531[0.472]$ & $F(1,28) 6.674[0.015]^{* *}$ \\
The Philippines & $F(1,28) 2.048[0.163]$ & $F(1,28) 1.242[0.274]$ \\
VAR (1) & $F(1,28) 1.298[0.264]$ & $F(1,28) 2.351[0.136]$ \\
VAR (1) & $F(1,28) 0.303[0.586]$ & $F(1,28) 0.918[0.346]$ \\
Thailand & VAR (1) &
\end{tabular}

Notes: $F$-statistics in a multivariate VAR of real money (M1 or M2), real foreign assets (FA), output, and the interest rate, with a constant term and seasonal dummies. Lag length (in parentheses following VAR) was chosen on the basis of Schwarz's Bayesian information criterion (SBIC). Numbers in brackets are $p$-statistics.

**Significant at the 5 percent level.

Another important channel of influence concerns how a change in FA might have affected the level of interest rates. Our earlier discussion suggested that effective sterilization would limit the growth of monetary aggregates and raise the level of interest rates at the same time. So far, the causality tests (along the lines of equation [1]) have suggested the possibility that sterilization was effective in limiting the growth of monetary aggregates. How then was the level of interest rates affected by sterilization, given a change in FA? Table 6.5 reports the results of multivariate causality tests in logarithmic differences (except for $i$, which is expressed in simple differences). The tests suggest, rather surprisingly, that no Granger causality was found from FA to the money market rate during 1987-97 for any of the countries, except for the Philippines, where causality was found at the 1 percent significance level regardless of whether M1 or M2 was used. This may mean that sterilization was effective, not necessarily in raising the level of interest rates, but in keeping it from falling toward the world interest rates. More will be said on this point in the concluding section.

6.2). On the basis of the procedure of Toda and Phillips (1993), the only evidence of causality (from FA to M1) was found for the Philippines at the 10 percent level of significance. Hence, our conclusion based on tables 6.3 and 6.4 does not change. 
Table 6.5 Granger Tests of Causality between Foreign Assets and the Interest Rate, 1987-97 (multivariate VAR)

\begin{tabular}{ccc}
\hline & \multicolumn{1}{c}{ FA causes $i$} & $i$ causes FA \\
\hline \multicolumn{1}{c}{ M1, $Y, i$, and FA (first row); M2, $Y, i$, and FA (second row) } \\
Indonesia & $F(1,28) 2.251[0.144]$ & $F(1,28) 2.009[0.167]$ \\
VAR (1) & $F(1,28) 1.791[0.191]$ & $F(1,28) 1.933[0.175]$ \\
VAR (1) & $F(1,28) 0.251[0.619]$ & $F(1,28) 0.011[0.913]$ \\
Korea & $F(1,28) 0.134[0.716]$ & $F(1,28) 0.011[0.915]$ \\
VAR (1) & $F(1,28) 0.239[0.628]$ & $F(1,28) 0.428[0.517]$ \\
VAR (1) & $F(1,28) 0.775[0.386]$ & $F(1,28) 0.234[0.631]$ \\
Malaysia & & \\
VAR (1) & $F(1,28) 12.27[0.002]^{* * *}$ & $F(1,28) 2.217[0.145]$ \\
VAR (1) & $F(1,28) 8.765[0.006]^{* * *}$ & $F(1,28) 1.569[0.220]$ \\
The Philippines & & \\
VAR (1) & $F(1,28) 0.268[0.608]$ & $F(1,28) 2.692[0.112]$ \\
VAR (1) & $F(1,28) 0.546[0.465]$ & $F(1,28) 0.327[0.571]$ \\
Thailand &
\end{tabular}

Notes: F-statistics in a multivariate VAR of real money (M1 or M2), real foreign assets (FA), output, and the interest rate, with a constant term and seasonal dummies. Lag length (in parentheses following VAR) was chosen on the basis of Schwarz's Bayesian information criterion (SBIC). Numbers in brackets are $p$-statistics.

***Significant at the 1 percent level.

\subsubsection{Tests of Structural Equations}

Second, as an additional test of the effect of foreign assets on the growth of monetary aggregates, we will estimate the following structural equation.

$$
\Delta \ln \left(\frac{\mathrm{M}_{t}}{P_{t}}\right)=d+h \Delta \ln \left(\frac{\mathrm{FA}_{t-1}}{P_{t-1}}\right)+q v+u_{t}
$$

where $\Delta$ is a first-difference operator, $\mathrm{M}$ is either $\mathrm{M} 1$ or $\mathrm{M} 2, d$ is a constant, $h$ is the coefficient of lagged foreign assets, $q$ is a vector of coefficients, $v$ is a vector of other explanatory variables, including seasonal dummies, $\Delta \ln Y$, and $\Delta i$, and $u$ is a random error term.

Equation (2) includes lagged FA, and not current FA, because a change in FA is believed to affect M1 or M2 over time through the banking sector. Use of lagged FA also has an additional advantage in that it alleviates the potential difficulty with M1 or M2 affecting FA contemporaneously. Moreover, in the light of the earlier causality test that, except for the Philippines, there was no causality between FA and $i$ in either direction, there is no need to worry about correlation between lagged FA and $i$, either (except for the Philippines, of course). However, equation (2) is estimated 
both with and without $i$ in order to check robustness. We are particularly interested in the estimated value of $h$.

Table 6.6 through table 6.10 (first two columns under each heading M1 or M2) report the results of estimating equation (2) by ordinary least squares (OLS) for Indonesia, Korea, Malaysia, the Philippines, and Thailand. The $F$-statistics are generally significant (except for Indonesia and Malaysia when M2 is used); considering that the regression equation is estimated in first-difference form, the $R^{2}$ is remarkably high, especially when M1 is used. The coefficient of output is positive when it is significant, while the coefficient of the interest rate is negative when it is significant. Many of the coefficients of the seasonal dummies (not formally reported in the tables) are significant.

From these tables, we find that regardless of whether M1 or M2 is used or whether $i$ is included, the coefficient of lagged FA $(h)$ is not significantly different from zero. The only exception is found for the Philippines when M2 is used and $i$ is included. Because of the potential simultaneity problem, not too much confidence can be placed in the present result at this time. So far as this result is concerned, however, the coefficient $(h)$ is negative, suggesting that a rise in foreign assets reduces M2 in the next period. All in all, the overall weight of the evidence seems to suggest that sterilization was effective in limiting the growth of monetary aggregates during 1987-97 in all countries, affirming the results of the Granger causality tests.

Finally, the tables (last two columns under each heading) also report the results of estimating equation (2) by including a slope dummy for the coefficient of $\Delta \ln \left(\mathrm{FA}_{t-1} / P_{t-1}\right)$, with the dummy indicating the intensity of sterilization

$$
\Delta \ln \left(\frac{\mathrm{M}_{t}}{P_{t}}\right)=d+h_{1} \Delta \ln \left(\frac{\mathrm{FA}_{t-1}}{P_{t-1}}\right)+\mathrm{DUM}_{t} h_{2} \Delta \ln \left(\frac{\mathrm{FA}_{t-1}}{P_{t-1}}\right)+q v+u_{t}
$$

where DUM is the dummy variable which takes the value of unity when sterilization is considered to be particularly intense, and $h_{1}$ and $h_{2}$ (replacing $h$ ) are the coefficients of lagged real foreign assets under normal conditions and under intense sterilization, respectively. The annual series of dummy variables were constructed on the basis of information provided by Villanueva and Seng (1999) and a similar construction of the sterilization index presented by Reinhart and Reinhart (1998) and Montiel and Reinhart (1999). The quarterly series are created by simply assuming that, during a given calendar year, they take the same value as the annual series. Here, sterilization was considered to be intense if open market operations were large in scale and accompanied by increased reserve requirements or transfers of government deposits from commercial banks to the central bank (see the annual series in table 6.11). 


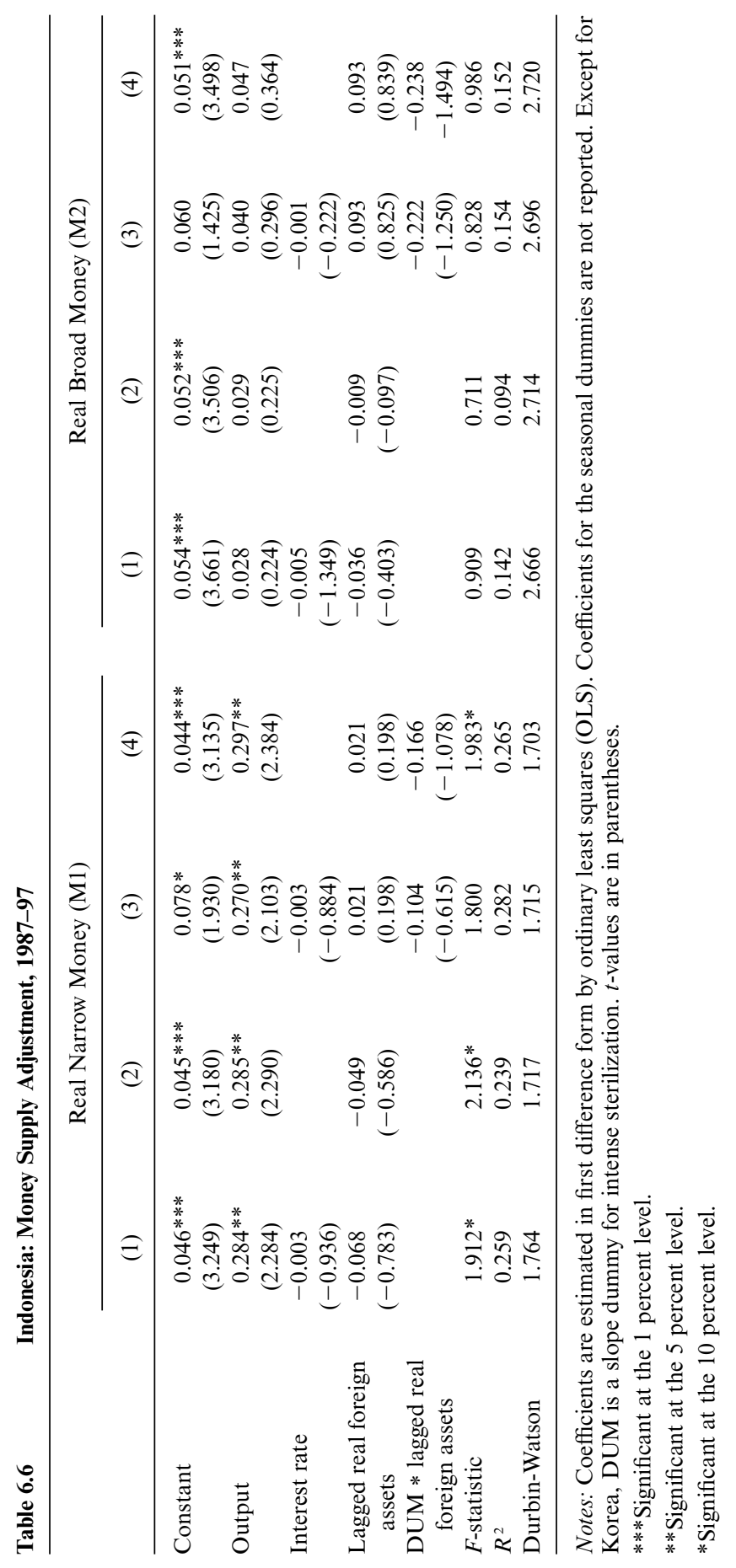


Korea: Money Supply Adjustment, 1987-97

\begin{tabular}{|c|c|c|c|c|}
\hline & \multicolumn{2}{|c|}{ Real Narrow Money (M1) } & \multicolumn{2}{|c|}{ Real Broad Money (M2) } \\
\hline & (1) & $(2)$ & (1) & (2) \\
\hline Constant & $\begin{array}{c}0.064 \\
(1.203)\end{array}$ & $\begin{array}{c}0.064 \\
(1.226)\end{array}$ & $\begin{array}{l}0.053^{* * * *} \\
(3.394)\end{array}$ & $\begin{array}{l}0.054^{* * *} \\
(3.459)\end{array}$ \\
\hline Output & $\begin{array}{c}0.280 \\
(0.879)\end{array}$ & $\begin{array}{c}0.278 \\
(0.897)\end{array}$ & $\begin{array}{c}0.064 \\
(0.681)\end{array}$ & $\begin{array}{c}0.062 \\
(0.679)\end{array}$ \\
\hline Interest rate & $\begin{array}{c}0.0003 \\
(0.033)\end{array}$ & & $\begin{array}{c}0.0003 \\
(0.134)\end{array}$ & \\
\hline Lagged real foreign assets & $\begin{array}{c}0.120 \\
(1.303)\end{array}$ & $\begin{array}{c}0.120 \\
(1.322)\end{array}$ & $\begin{array}{c}0.040 \\
(1.466)\end{array}$ & $\begin{array}{c}0.040 \\
(1.484)\end{array}$ \\
\hline$F$-statistic & $10.97 * * *$ & $16.13 * * *$ & $16.13 * * *$ & $19.93 * * *$ \\
\hline$R^{2}$ & 0.666 & 0.746 & 0.746 & 0.746 \\
\hline Durbin-Watson & 2.680 & 2.738 & 2.738 & 2.743 \\
\hline
\end{tabular}

Notes: See table 6.6.

$* * *$ Significant at the 1 percent level.

We consider equation (3) in order to see whether the relationship between FA and monetary aggregates was invariant through time. If the policy of intense sterilization was particularly effective in limiting the impact of an increase in FA on the growth of M1 or M2, we should expect the value of $h_{2}$ to be negative, so that the coefficient of $\left(\mathrm{FA}_{t-1} / P_{t-1}\right)$ under intense sterilization (i.e., $h_{1}+h_{2}$ ) is algebraically smaller than that under normal conditions $\left(h_{1}\right)$. Because no sterilization was considered intense in Korea, the results are reported for the other four countries only. The last two columns under each heading show that the coefficient $h_{2}$ is not statistically significant in any of the countries regardless of whether M1 or M2 is chosen (confirming the earlier results obtained without the slope dummies), although it is indeed negative in Indonesia, the Philippines, and Thailand. We can thus reaffirm our earlier conclusion that sterilization was effective in limiting the growth of monetary aggregates during 198797, with the additional insight that the effectiveness of sterilization was indeed greater (albeit marginally) when it was intense.

\subsection{Conclusion}

The East Asian countries of Indonesia, Korea, Malaysia, the Philippines, and Thailand received large volumes of capital inflows from the end of the 1980s through early 1997. The cumulative inflows were massive indeed, amounting to 50 percent of GDP in Malaysia and Thailand, more than 20 percent in the Philippines, and about 10 percent in Indonesia and Korea. Although a large portion of the inflows initially took the form of FDI, they increasingly took the form of offshore borrowing by banks and 


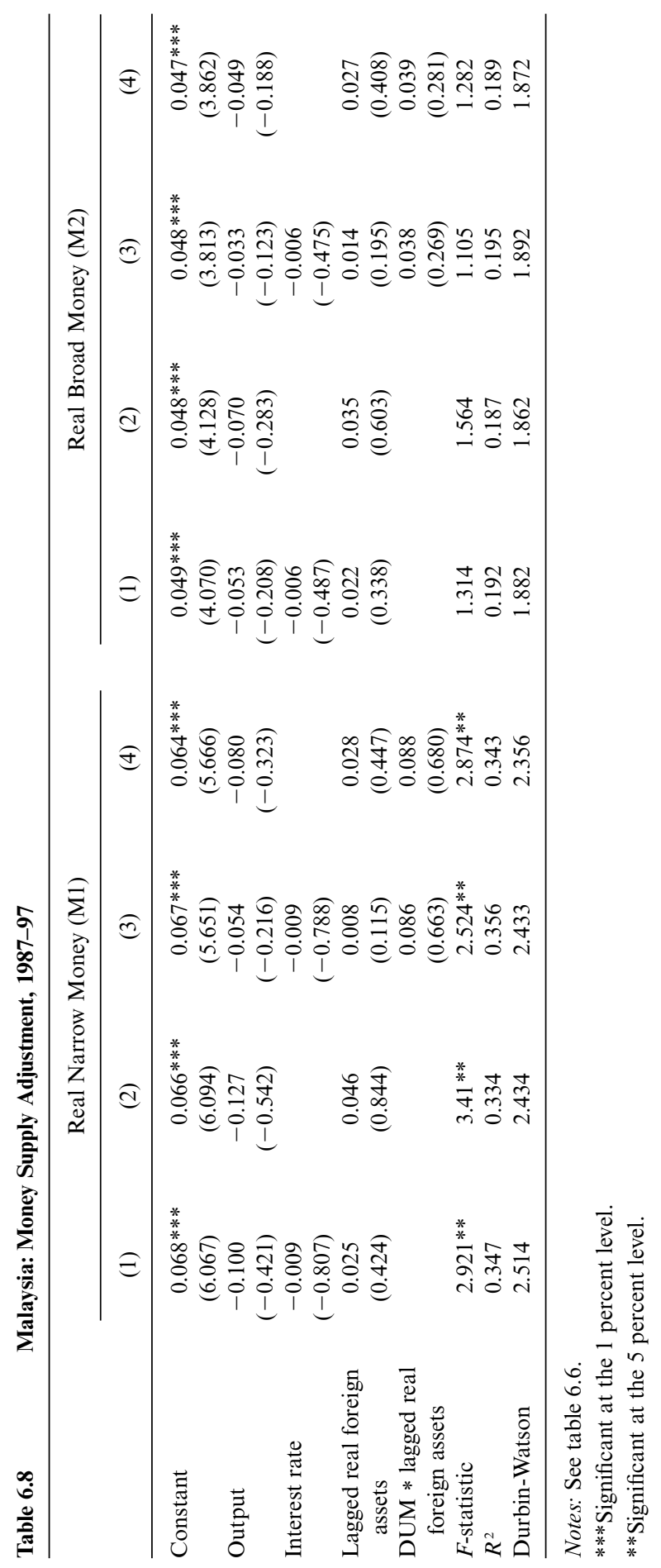




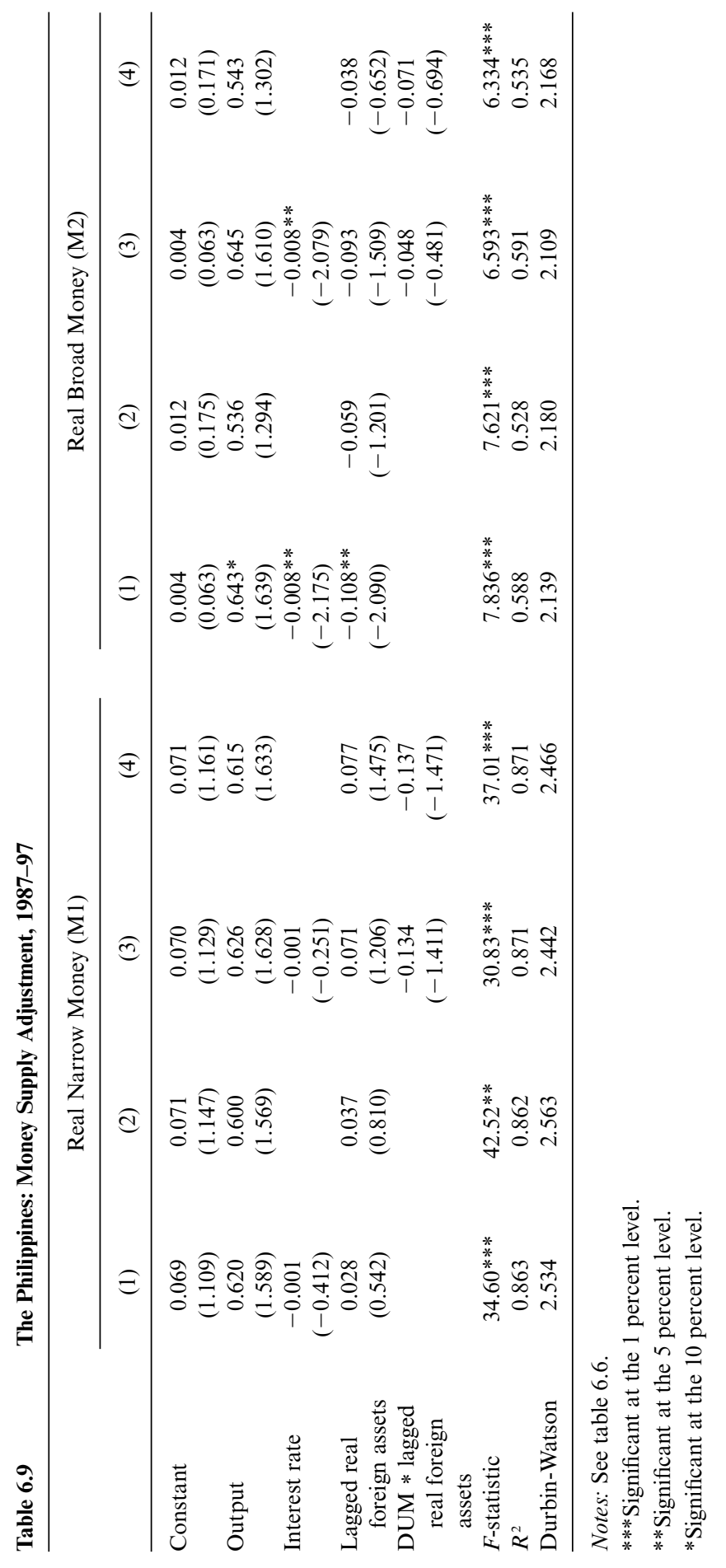




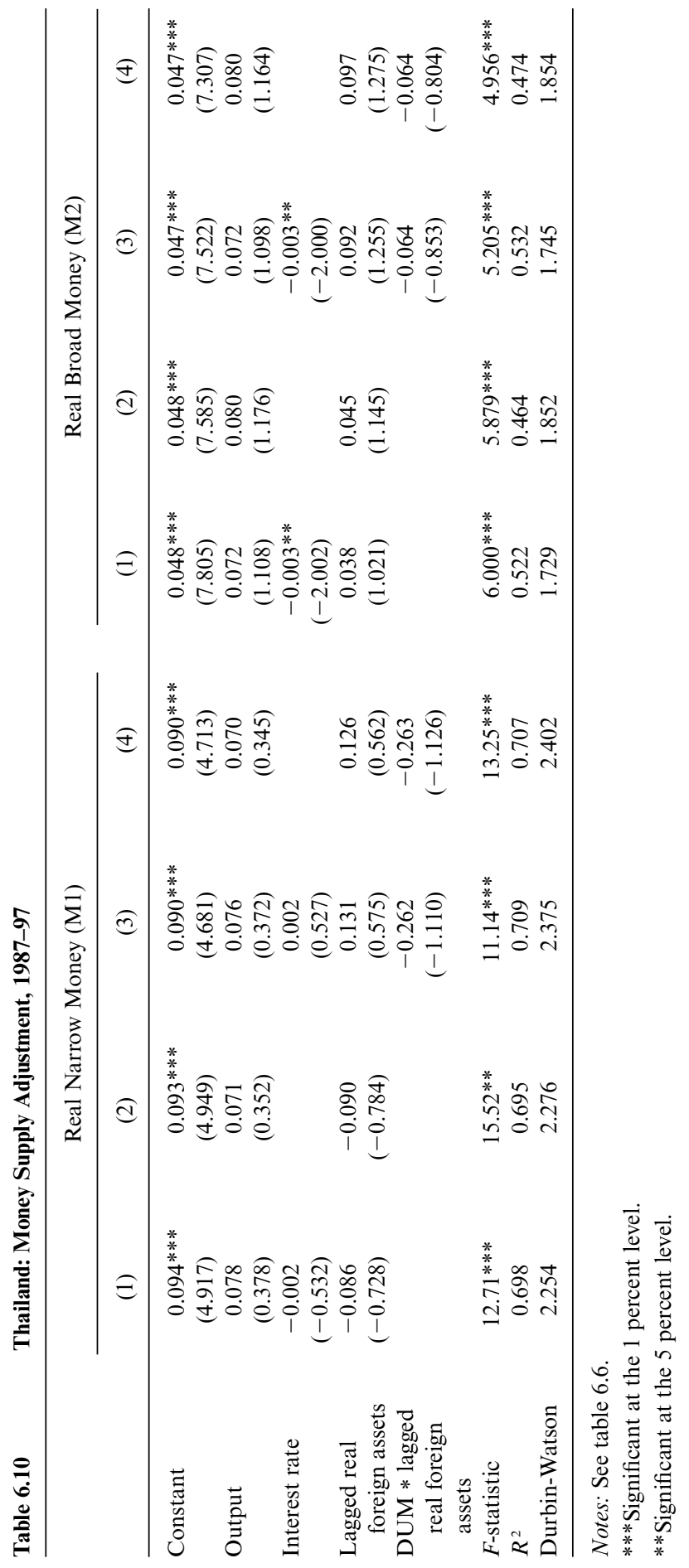


The "Intense Sterilization" Dummy

\begin{tabular}{cccccc}
\hline & & & & \multicolumn{2}{c}{ The } \\
& Indonesia & Korea & Malaysia & Philippines & Thailand \\
\hline 1987 & 0 & 0 & 0 & 0 & 0 \\
1988 & 0 & 0 & 0 & 0 & 0 \\
1989 & 0 & 0 & 0 & 0 & 0 \\
1990 & 0 & 0 & 0 & 1 & 1 \\
1991 & 1 & 0 & 1 & 0 & 1 \\
1992 & 1 & 0 & 1 & 0 & 0 \\
1993 & 0 & 0 & 1 & 0 & 0 \\
1994 & 0 & 0 & 0 & 0 & 0 \\
1995 & 0 & 0 & 0 & 0 & 1 \\
1996 & 1 & 0 & 1 & 0 & 0 \\
1997 & 0 & 0 & 0 & 0 & 0 \\
\hline
\end{tabular}

Sources: The authors' judgment based on Reinhart and Reinhart (1998), Montiel and Reinhart (1999), and Villanueva and Seng (1999).

Notes: Sterilization is considered intense (i.e., a value of unity is assigned) if open market operations were large in scale and accompanied by increased reserve requirements or transfers of government deposits from commercial banks to the central bank. The quarterly series for a given year are assumed to have the same value as the annual series.

nonbank private corporations in later years. Because of the potential risks they entail, these capital inflows were, almost from the inception, considered as posing a serious challenge for macroeconomic management, leading the profession to coin the expression "the capital inflow problem."

An important aspect of the capital inflow episode was that the volume of inflows far exceeded the current account deficits, such that the increases in foreign exchange reserves amounted to $25-35$ percent of the net capital inflows. Needless to say, the accumulation of reserves was the result of foreign exchange market intervention to maintain the level of nominal exchange rates. Short of allowing the exchange rate to appreciate, the East Asian monetary authorities responded decisively to the massive reserve inflows, first by the conventional form of sterilization and then by taking a wide range of measures to limit the effect of the reserve inflows on the growth of monetary aggregates, the measures which are called "broadly defined sterilization" in this paper.

We began the paper by noting that, whether narrowly or broadly defined, effective sterilization should not only limit the growth of monetary aggregates in response to an increase in foreign assets, but also raise the level of domestic interest rates. The resulting tight monetary condition (often supported by tight fiscal policy) and higher domestic interest rates should then promote additional capital inflows. The Granger causality tests and OLS estimates of structural parameters, however, gave the somewhat perplexing results indicating that, while sterilization was apparently effective in fully limiting the growth of monetary aggregates arising from 
an increase in foreign assets, it was not causing the level of interest rates to rise.

At this point, a word of reservation might be expressed about the nature of the methodologies used. We noted at the outset that, given the variety of tools used to mitigate the impact of reserve inflows on the growth of monetary aggregates in these countries, the conventional method of estimating the offset coefficient of the capital flow equation along with the monetary-policy reaction function would be inappropriate as a test of the effectiveness of sterilization. Instead, what we decided to do was to use a "black box" way of measuring the effectiveness of sterilization, by essentially estimating the statistical significance of FA in the equation describing the growth of M1 or M2, without explicitly considering how sterilization is actually effected. While we believe that this is an intuitively appealing procedure, given the ultimate objective of sterilization, we also recognize that it may be subject to potential problems. For instance, the lack of statistical significance may reflect, not the effectiveness of sterilization, but the much smaller magnitude of FA relative to that of either M1 or M2; the results may also be sensitive to the choice of lag length, particularly when the methodologies are applied in first-difference form. In the future, it will be useful to check the robustness of our methodologies against alternative specifications or alternative sample countries. ${ }^{12}$

Subject to these and other limitations, our results (suggesting the effectiveness of sterilization, while indicating little evidence of an interest rate rise) are capable of yielding two possible interpretations. First and most likely, the lack of evidence linking a rise in foreign assets to a rise in interest rates may simply suggest that sterilization was effective, not necessarily in raising the level of interest rates, but in keeping it from falling toward the lower world-interest rates. To support this claim, the moving average representations of the estimated vector autoregression (VAR) system (reported earlier) suggest that interest rates do rise in response to an innovation in foreign assets in all countries except Korea (fig. 6.6). It is also possible that a more systematic relationship between foreign assets and interest rates might have been evident for a more appropriate interest rate or interest rate differential. In Indonesia, for example, it is said that the interest rate on SBIs rose sharply from 11.6 percent in 1988 to 18.8 percent in 1990 and 21.5 percent in 1991; Furman and Stiglitz (1998) note that interest rate differentials did widen in East Asian countries over the period of sterilization. ${ }^{13}$

12. In this context, as a robustness check, the referee has suggested the usefulness of applying our methodologies to countries under currency boards. Data limitations, however, have prevented us from pursuing this course.

13. According to Furman and Stiglitz (1998), in Thailand, short-term money market rates rose 400 basis points above comparable U.S. interest rates in 1996, and similar spreads were observed for other East Asian countries. 

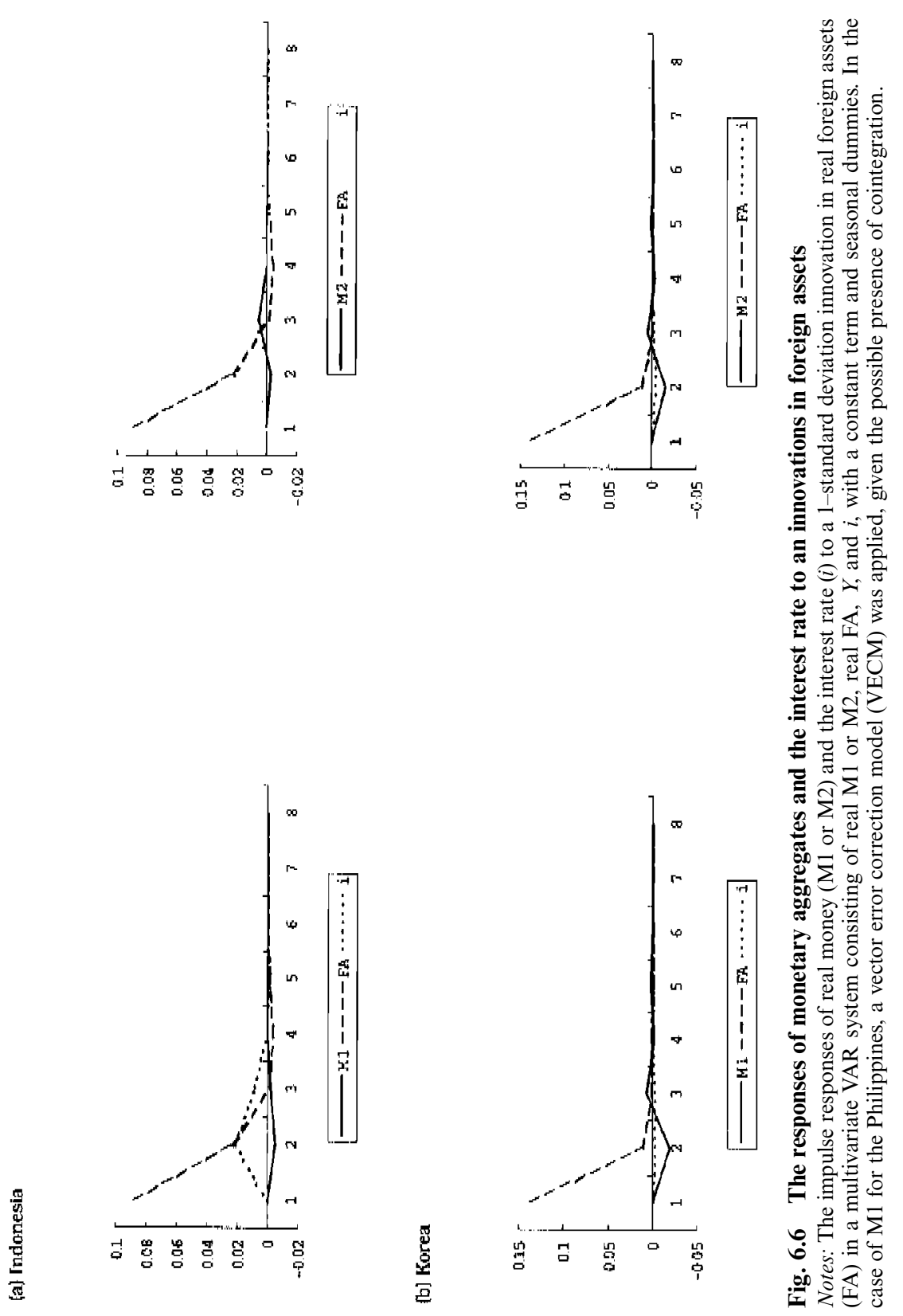

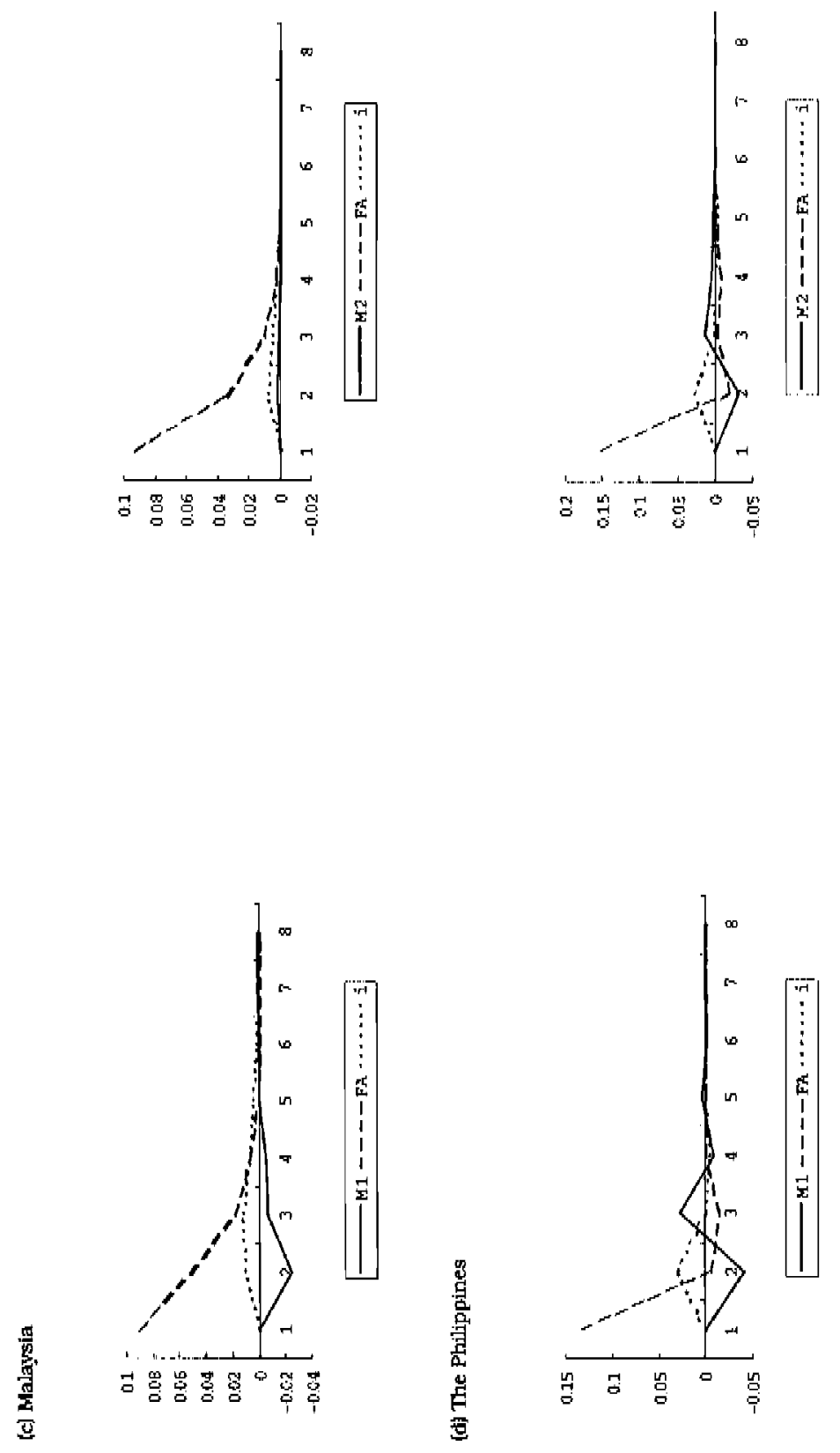

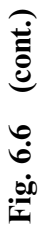



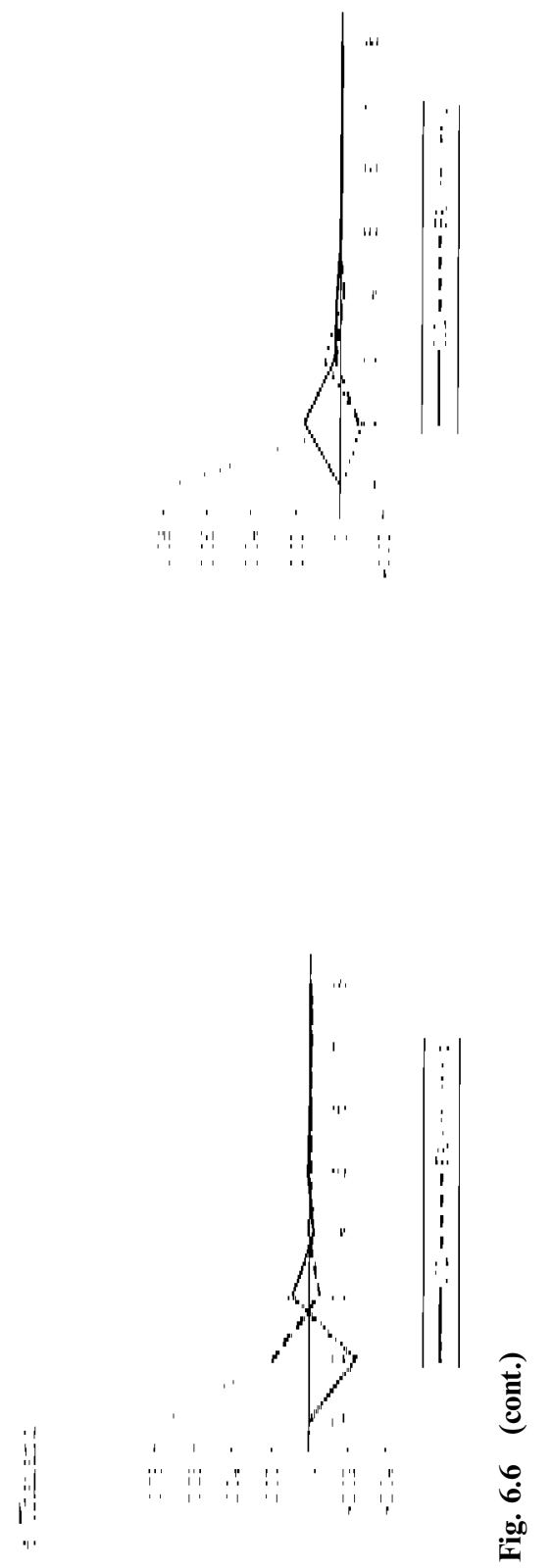
Second, as another possible interpretation of the seeming lack of evidence on the interest rate channel, it is possible that sterilization was not so effective in limiting the growth of overall monetary assets, although it was effective in limiting the growth of $\mathrm{M} 1$ or M2 which is under the supervised banking sector. Although broadly defined sterilization measures (such as changes in reserve requirements, credit controls, and moral suasion) may be effective against the supervised banking sector, they may result in disintermediation in an environment where there is a viable nonbank financial sector. In the case of Korea, for example, Spiegel (1995) documents that the share of assets controlled by the banking sector declined over the period 1986-93, although no such evidence was found for the Philippines and Malaysia, where the nonbank financial sector is not well developed. It should be noted that this disintermediation interpretation is not necessarily incompatible with the story that sterilization kept the level of interest rates high.

In either case, the policy of sterilization pursued by the monetary authorities of East Asia during the capital inflow episode was effective in fully limiting the growth of M1 or M2, and possibly magnified the risk of capital inflows by keeping the level of interest rates high (hence promoting additional capital inflows), by channelling resources to the relatively unsupervised nonbank financial sector, or both. In this context, the work of Montiel and Reinhart (1999) suggests that the sterilization policy of the Asian monetary authorities not only magnified the volume of capital inflows but also skewed the composition of capital flows towards short-term maturities. Both through additional capital inflows with a short-term bias and through possible disintermediation, it is likely that the capital inflow problem of East Asia leading up to the crisis of 1997 was made more serious by the active and persistent policy of sterilization.

\section{Appendix}

\section{Sources of Data}

Except for industrial production in Indonesia and Thailand (which were obtained from the Bank of Japan's economic database), all data were obtained from the International Monetary Fund, International Financial Statistics, as follows. Foreign Assets (FA) were obtained from line 11. Narrow money (M1) and quasi-money were obtained from lines 34 and 35, respectively; M1 and quasi-money constitute broad money (M2). Interest rates were obtained from the money market rate (line 60b) for Indonesia, Korea, Malaysia, and Thailand, and from the Treasury bill rate (line 60c) for the Philippines. 


\section{References}

Alba, Pedro, Amar Bhattacharya, Stijn Claessens, Swati Ghosh, and Leonard Hernandez. 1998. The role of macroeconomic and financial sector linkages in East Asia's financial crisis. unpublished, World Bank. 1998. Mimeograph.

Bartolini, Leonardo, and Allan Drazen. 1997. Capital-account liberalization as a signal. American Economic Review 87 (March): 138-54.

Calvo, Guillermo A. 1991. The perils of sterilization. IMF Staff Papers 38 (December): 921-26. Washington, D.C.: International Monetary Fund.

Calvo, Guillermo A., Leonard Leiderman, and Carman M. Reinhart. 1996. Inflows of capital to developing countries in the 1990s. Journal of Economic Perspectives 10 (Spring): 123-39.

Chen, Zhaohui, and Mohsin S. Khan. 1997. Patterns of capital flows to emerging markets: A theoretical perspective. IMF Working Paper no. 97/13. Washington, D.C.: International Monetary Fund, January.

Chuhan, Punam, Stijn Claessens, and Nlandu Mamingi. 1998. Equity and bond flows to Latin America and Asia: The role of global and country factors. Journal of Development Economics 55 (April): 439-63.

Furman, Jason, and Joseph E. Stiglitz. 1998. Economic crises: Evidence and insights from East Asia. Brookings Papers on Economic Activity, issue no. 2:1-135. Washington, D.C.: Brookings Institution.

International Monetary Fund (IMF). Various months. International financial statistics. Washington, D.C.: International Monetary Fund.

Isard, Peter. 1995. Exchange rate economics. Cambridge: Cambridge University Press.

Johansen, Soren. 1988. Statistical analysis of cointegration vectors. Journal of Economic Dynamics and Control 12 (June/September): 231-54.

Kletzer, Kenneth, and Mark M. Spiegel. 1998. Speculative capital inflows and exchange rate targeting in the Pacific basin: Theory and evidence. In Managing capital flows and exchange rates: Perspectives from the Pacific Basin, ed. Reuven Glick, 409-35. Cambridge: Cambridge University Press.

Montiel, Peter J. 1998. The capital inflow problem. World Bank Institute Working Paper no. 37135. World Bank, Economic Development Institute, January.

Montiel, Peter J., and Carmen M. Reinhart. 1999. Do capital controls and macroeconomic policies influence the volume and composition of capital flows? Evidence from the 1990s. Journal of International Money and Finance, 18 (August): 619-35.

Radelet, Steven, and Jeffrey Sachs. 1998. The onset of the East Asian financial crisis. NBER Working Paper no. 6680. Cambridge, Mass.: National Bureau of Economic Research.

Reinhart, Carmen M., and Vincent Raymond Reinhart. 1998. Some lessons for policy makers: Dealing with the mixed blessing of capital inflows. In Capital flows and financial crises, ed. M. Kahler, 93-127. New York: Council on Foreign Relations.

Spiegel, Mark M. 1995. Raising reserve requirements in response to Asian capital inflow surges. Federal Reserve Bank of San Francisco, Weekly Newsletter no. 95-41, 1 December.

Takagi, Shinji. 1986. Rediscount policy and official capital flows: A study of monetary control in Central America in the 1950s. Journal of Money, Credit, and Banking 18 (May): 200-10.

. 1999. The yen and its East Asian neighbors, 1980-1995: Cooperation or competition? In Changes in exchange rates in rapidly developing countries: The- 
ory, practice, and policy issues, ed. Takatoshi Ito and Anne O. Krueger, 185-210. Chicago: University of Chicago Press.

Toda, Hiro T., and Peter C. B. Phillips. 1993. Vector autoregressions and causality. Econometrica 61 (November): 1367-93.

Toda, Hiro T., and Taku Yamamoto. 1995. Statistical inference in vector autoregressions with possibly integrated processes. Journal of Econometrics 66 (March/ April): 225-50.

Villanueva, Delano, and Lim Choon Seng. 1999. Managing capital flows in SEACEN countries: A policy agenda. Southeast Asian Central Banks Research and Training Centre, February. Mimeograph.

\section{Comment Leonard K. Cheng}

A factor widely considered critical to the East Asian financial crisis in 1997-98 is its enormous short-term foreign debt. This paper examines the extent to which the "capital inflow" problem was induced by the "sterilization" policy or equivalently tight monetary policy pursued by the East Asian governments. It goes on to test whether sterilization was effective in limiting the growth of monetary aggregates during the decade before the East Asian financial crisis. The questions raised in this paper are both interesting and timely.

An inflow of capital (as measured by the foreign asset in the monetary base, abbreviated as FA) will put downward pressure on the domestic interest rate, other things being equal. The effect of any sterilization policy is to keep the domestic interest rates in the East Asian economies higher than otherwise, thus inducing an additional amount of capital inflow. I agree with this logic, but I also think the time dimension should be explicitly recognized.

In one example, capital flows in, the interest rate falls in response, sterilization policy kicks in, and the aggregate money supply drops, thus pushing up the interest rate. In another example, sterilization policy kicks in as soon as capital flows in, and the movement of the interest rate depends on the extent of sterilization. The interest rate will fall by an amount that is smaller than that without sterilization if sterilization serves to offset the capital inflow only partially. In contrast, if sterilization serves to more than offset the capital inflow, then the interest rate will rise. Which of these examples fits the quarterly data better? Do the responses of the monetary aggregates and interest rates to an innovation in FA as summarized in figure 6.6 of the paper imply that sterilization was more than offsetting the capital inflow? Or were both responses the results of an increase in demand

Leonard K. Cheng is professor of economics at the Hong Kong University of Science and Technology. 